短報

\section{イネ芽出し苗によるコブノメイガの 簡易大量飼育法}

\author{
藤吉 臨・野出政春・酒井久夫 \\ 福湖県立農業試験場
}

Simple Mass-Rearing Method of the Grass Leaf Roller, Cnaphalocrocis medinalis Guenée, on Young Rice Seedlings. Nozomu Fujiyoshi, Masaharu NoDA and Hisao SAKAI (Fukuoka Agricultural Experiment Station, Chikushino, Fukuoka 818). Jap. J. appl. Ent. Zool. 24 : 194196 (1980)

寄主植物を用いて 食葉性昆虫を, 大量に飼育する場合には, 種々の難点が生ずる（楊鴆，1970）。しかし，幼植物を餌として 食葉性昆虫を大量に 飼育する方法は，い安守でいくつか報告 されている(佐藤, 1964; 腰原·山田, 1976; 中筋·本多, 1979)。このような飼育法においては, 慨となる寄主植物の種 子の入手がきわめて容易で，しかも安価であることが重要であ る。

コブノメイガはイネの葉を巻いて表皮を摂食する習性をもつ ため, 効辩的な大量飼育法がまだ確立されていない。そのため, 本種の生理・生態及び防除上の基礎的実験などに 供試する個体 を，周年にわたって大量に得ることが困難であった。そこで，

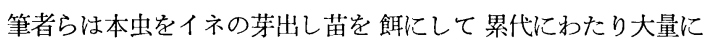
飼育する方法を検討したところ, ほぼこの目的を達することが できたので，ここにとの方法を報告する。

\section{材料及び方法}

\section{1. 飼料の作り方}

幼虫の飼料としてのイネの芽出し苗は，通常の機械移植用箱 苗を育成する要領で, 夏期には寒冷紗張りの網室 (自然日長), 冬期には加温ガラス室 $\left(10 \sim 30^{\circ} \mathrm{C}\right.$, 自然日長) あるいは人工照 明下の室内 $\left(24 \pm 3^{\circ} \mathrm{C}\right)$ で育てた。すなわち，まずイネ種子を 水選した 後 4 日間水に浸漬して発芽させ, この種子を田植機用 育苗専用床土 (クミアイ合成培土 2 号: 三井東压化学製) 索深さ $2 \mathrm{~cm}$ につめたプラスチック製バット $(20 \times 28 \times 4 \mathrm{~cm})$ に $60 \mathrm{~g}$ （乾燥種子重）播き，軽く覆土した。次に播種後芽の伸長を促進 させるため, バットを $4 \sim 5$ 段に積重ねてビニールで被覆し， 4 日間放置した後鞘葉が $2 \mathrm{~cm}$ 程度伸長したころ，バットを平面 に広げた。その後は本葉 2.5 葉程度になるまでまって（約 20
日間)，幼虫の慨として用いた。

なお，定温人工照明下で苗を育てる場合には，苗の徒長が著 しいので，徒長抑制のため殺菌剂タチガレン®液（500 倍, 200 $\mathrm{m} l$ /箱) を播種時, その 1 週間及び 2 週間後の 3 回潅注した。 れにより苗の徒長をかなり抑制することができた。

\section{2. 供試虫}

飼育虫は, 1979 年 8 月に当試験場内の固場で採集した終令幼 虫を、イネの葉を与えて室内で飼育したものの子孫である。

\section{3. 採卵・幼虫の接種及び飼育}

本虫は卵を 1 数粒ざつ点々と産下するため, 効率的な採卵 法を採用する必要があった。そこで，中山・小島（1978）の方法 にしたがい，ポリェチレン製袋 $(23 \times 34 \mathrm{~cm})$ に羽化 3 日後の雌 雄 3〜4 対を入れ，慨として八チミッ $5 \%$ 液を含ませた綿球を 与兄て 3 日おいたところ，1袋当たり約 200 個の卵が得られ た。その際, 袋から成虫及び八チミッ綿球を取除き, 湿度保持 のため新たに水を含ませた綿球を入れて，しばらく扎いた。袋 の内面に産まれた卵が 発育してわずかにふ化幼虫が出現する

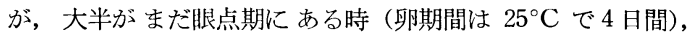
袋の長辺と底辺をナイフで切って広げ，乙れを芽出し苗の上に 被せた (第1四左)。このようにして 2 日間袋を被せておくと， ほとえどの卵はふ化し，ふ化幼虫はイネ苗の下方へ移動し，葉 を巻いて摂食しはじめた。なお，ふ心化幼虫を接種した後は蛹化 まで，芽出し苗が枯死しない上うに時々潅水した。

幼虫が終令になると，イネ苗の葉を数枚つら゙り合わせて，ほ とんどの葉を食いつくした(第1 図右)。蛹化はこのつゔり合わ せた葉の中で行われるので, 半数近くが蛹化した時期に地際部

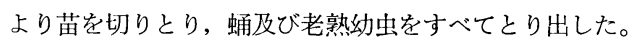

なお, 芽出し苗が本葉 3 枚目を展開して草丈が $15 \mathrm{~cm}$ 程度で あれば，接種から蛹化まで䬣換光の必要はなかった。しかし， それ以上に徒長した苗では 1〜2 回の䬣換えを行う必要があっ た。䬣換光は, 新しい苗箱を, 古い箱に互いにイネの葉が接触 するように斜めにたてかけ，翌日箱をそれでれ反転してやれば， ほとえどの幼虫は自力で新しい苗箱へ移った。

\section{結果及び考察}

筆者らは，今までに網箱の中へ投入したイネの芽出し苗に成 虫を放つ方法，あるいはプラスチック製容器内で採卵した卵か らのふ化幼虫を, 小筆でイネ不苗に接種する方法を試み, 芽出し苗 でも幼虫は十分発育できることを経験していた。しかし，これ らの方法では一度に多数の老熟幼蚆蛹を得るには多大の労力 がかかり，しかもかなり広い空間を必要とする難点があった。

そこで, コブノメイガやハスモンヨトウ（中山・小島，1978） などが，ポリエチレン製の袋内表面に容易に産卵する性質を利 用し、ポリエチレン袋に産卵させた卵からのふ化幼虫を直接芽 出し苗に接種する方法を試みた。その結果, この方法によると, 


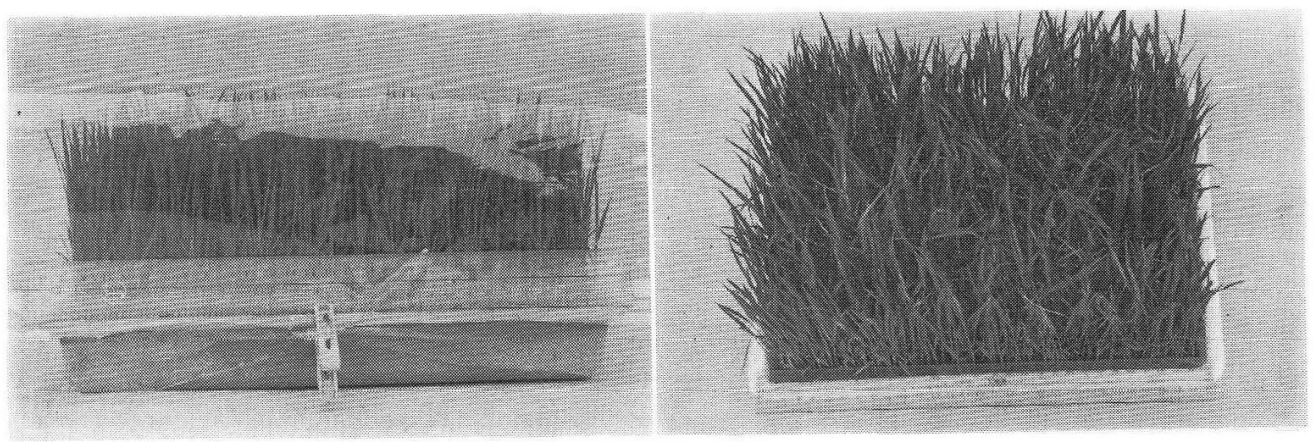

第1図 ふ化幼出の接種方法（左）と終令幼虫の食害状態 (右).

第 1 表 接種 16 日後の幼虫の発育状態

\begin{tabular}{|c|c|c|c|c|c|c|}
\hline \multirow{2}{*}{$\begin{array}{c}\text { 飼育温度 } \\
\left({ }^{\circ} \mathrm{C}\right)\end{array}$} & \multirow{2}{*}{ 供試箱数 } & \multicolumn{4}{|c|}{ 発育ステージ別虫数（頭/箱） } & \multirow{2}{*}{$\begin{array}{l}\text { 合計数 } \\
\text { (頭/箱) }\end{array}$} \\
\hline & & 蛹 殷 & 蛹 & 前 蛹 & 老熟幼虫 & \\
\hline 27.7 & 7 & $\begin{array}{c}1.1 \pm 1.2^{\mathrm{a}} \\
(1.4)^{\mathrm{b}}\end{array}$ & $\begin{array}{c}63.6 \pm 17.5 \\
(80.6)\end{array}$ & $\begin{array}{c}12.1 \pm 3.9 \\
(15.3)\end{array}$ & $\begin{array}{c}2.1 \pm 1.5 \\
\quad(2.7)\end{array}$ & $\begin{array}{c}78.9 \pm 20.3 \\
(100.0)\end{array}$ \\
\hline 24.0 & 4 & $\begin{array}{c}0 \\
(0)\end{array}$ & $\begin{array}{c}29.5 \pm 7.1 \\
(37.9)\end{array}$ & $\begin{array}{c}20.8 \pm 9.2 \\
(26.7)\end{array}$ & $\begin{array}{c}27.5 \pm 7.7 \\
\quad(35.4)\end{array}$ & $\begin{array}{c}77.8 \pm 16.8 \\
(100.0)\end{array}$ \\
\hline
\end{tabular}

a 平均 $\pm 95 \%$ C. L.

b 総虫数に対する割合 $(\%)$.

本種のように大きな卵塊でないものでも採卵は容易で, しかも 幼虫の接種やその後の飼育操作も比較的簡単で, 一度にかなり 大量の蛹や老熟幼虫它得ることができた。

この方法を用いて，27.7 ${ }^{\circ} \mathrm{C}$ 及び $24^{\circ} \mathrm{C}, 16$ 時間照明下で, 16 日目に蛹と老熟幼虫をとり出した結果を第1 1 表に示した。蝻化 率は $27.7^{\circ} \mathrm{C}$ で約 $80 \% ， 24^{\circ} \mathrm{C}$ では 40\% で，とり出した幼虫 は両区とも老熟態であり, 発育は比較的斉一であった。幼虫期 間は当然ながら高温で短く, 佐藤・岸野 (1978)の行った個体䬦 育のそれに比べて，大きな差はなかった。

苗箱 1 箱当たりの最終的な蛹及び老熟幼虫数は, 半均すると 両温度区とも約 80 頭（60〜120 頭）であった。

この方法で集団的に飼育して得た蛹と, 芽出し苗の葉を与え た個休飼育による蛹の重量とを比較すると，第2 表のとおりで ある。この方法では強度の集団飼育となり，イチモンジセセリ の場合と同様に（中筋・本多，1979）, 蛹はかなり小形となっ た。蛹重は $27.7^{\circ} \mathrm{C}$ 何育ではかなり軽く, 㢳れより羽化した成
虫の交尾及び産卵虫率はかなり低かった。しかし， $24^{\circ} \mathrm{C}$ 飼育 で得られた程度の体重の蛹であれば, それから羽化した成虫は 正常に交尾・産卵し，産卵数も個体飼育で得られたものよりも 若干少ない程度であった。このような小形の成虫も, 羽化直後 からハチミッを与えておけば，かなりよく産卵すること岂確め たので，近親交配をさける手段をとれば継代飼育が可能であ ๖。

筆者らは現在この芽出し苗による本虫の飤育を，6世代 (1980 年 3 月末現在）にわたって継続するのに成功している。この方 法によると, ニカメイガ(佐藤, 1964) やイチモンジセセリ（中 筋·本多, 1979) の場合のように, ひえ繁な飭換えも不必要で, せいぜい 2 回程度で十分である。しかも，本虫は光周感応によ る発有遲延を起こさないので（佐滕・岸野，1978）, イネの芽出 し苗をいつでも使用できるょうにしておけば, 容易に継続的な 哃育が可能であると同時に，一度に大量を飼育することもでき る。

第 2 表 個体飼育出に対する集団飤育虫の蛹重の比較

\begin{tabular}{|c|c|c|c|c|c|}
\hline \multirow{2}{*}{ 飼育方法 } & \multirow{2}{*}{$\begin{array}{l}\text { 餇育温度 } \\
\left({ }^{\circ} \mathrm{C}\right)\end{array}$} & \multicolumn{2}{|c|}{ 雌 } & \multicolumn{2}{|c|}{ 雄 } \\
\hline & & 測定虫数 & 蛹重（mg） & 測定虫数 & 蛹重 (mg) \\
\hline 団 & 27.7 & 101 & $13.2 \pm 0.6^{\mathrm{a}}$ & 85 & $15.9 \pm 0.7$ \\
\hline & 24.0 & 117 & $15.1 \pm 0.4$ & 160 & $17.2 \pm 0.3$ \\
\hline 個 体 & 24.0 & 66 & $19.2 \pm 0.8$ & 72 & $20.6 \pm 0.7$ \\
\hline
\end{tabular}

\footnotetext{
a 平均 $\pm 95 \%$ C. L.
} 
引用文献

腰原達雄·山田偉雄 (1976) 応動昆 20 : 110-114.

中筋房夫·本多八郎 (1979) 応動昆 $23: 118-120$.
中山 勇·小島一郎 (1978) 応動昆 $22: 126-128$.

佐藤テイ・岸野賢一 (1978) 東北農試研報 $58: 47-80$.

佐藤安夫 (1964) 応動昆 8:6一10.

湯嶋 健（1970）農及園 46:1631-1636.

\section{新 刊 紹 介}

日本農学 50 年史 日本農学会 編 (1980) 東京 : 養 賢堂, 353 p.

日本農学会は昭和 4 年 (1929年), 明治初期から大正年間にか けて次第に近代科学として発展して来ていた農学に関連する諸 学会が連合して結成され, 昭和 54 年（1979 年）に50 周年を迎 えた。これを記念して本書は編さんされた。内容は 3 編に分か れ, 第 1 編は「日本農学研究を推進してきたもの」をテーマに, 大学や農業に関連する各種の試験場の果した役割, また実際に 生産を行っている農業者の技術が果した役割について論じられ ている。第 2 編は日本農学会に属する各学会が独自に, それぞ れの分野の発展, 学会の歴史のあとをとりまとめており, 本書 の 4 分の 3 を占めている。創立当時に参加したのは 16 学会で あったが, 現在では 26 学会に増加しており, 比較的新しい所で
は, 日本生物環境調節学会, 農業施設学会, 日本農薬学会, な どがある。

日本応用動物昆虫学会の担当部分は 13 頁で, 昆虫生理学, 合 成殺虫剤の利用，ウイルス媒介昆虫など 10 のトピックスについ てのべられている。紙面割り当ての制限からすべての分野を網 らすることは難しかったようで, 重要な分野でふれられていな いものもいくつか見られる。

第 3 編は日本農学会の史料で, 目ぼしい出来事が年次毎に集 められており, また日本農学会大会の講演会, 討論会, シンポ ジュウムの題目なども整理されている。

定価は 5,000 円であるが、各学会を通じて申込めば送料含み で 4,500 円である。

(農事試 岸本良一) 